\title{
When Bereaved of Everything: Objects from the Concentration Camp of Ravensbrück as Expressions of Resistance, Memory, and Identity
}

\author{
Johanna Bergqvist Rydén ${ }^{1}$
}

Published online: 27 July 2017

C) The Author(s) 2017. This article is an open access publication

\begin{abstract}
When survivors from the Ravensbrück concentration camp arrived in Sweden in spring 1945, some of the objects they brought with them from the camp were collected and preserved. These are modest in appearance, but were - as oral testimonies show - invaluable in camp. The concentration camp context of obliteration stretches the limits of interpretation of material culture to its extreme. In this article the objects are discussed as expressions of resistance, memory, and identity. These immaterial values were among the most vital coping strategies used by the prisoners against the dehumanization laid upon them by the camp administration. The material culture was central in enabling, upholding, and realizing these.
\end{abstract}

Keywords Ravensbrück $\cdot$ Material culture $\cdot$ Resistance $\cdot$ Memory $\cdot$ Identity

\section{Introduction}

The social significations and cultural contextual implications of objects are continually discussed within the disciplines of material culture. Now and then the material remains of the concentration camp infernos of WWII are used as a means to put into perspective the potential power of an object, the possible multiple layers of meanings, and representations beyond the obvious (e.g., Cole 2013; Kelly 2010; Klang Eriksson 2002). The symbolic and existential density of the material cultures of concentration camps thus serves to illustrate the gravity of meanings that objects have the potential to carry, and as such they are a powerful tool: the context of obliteration stretches the limits of interpretation of material culture to its extreme.

Johanna Bergqvist Rydén

Johanna.bergqvist_ryden@ahu.lu.se

1 Department of Historical Archaeology and AHU, MNO-huset, Lund University, Box 117,

S-22100 Lund, Sweden 
This material culture is, however, to an increasing extent also being studied and discussed for its own sake, for the information it carries not only about the potency of material culture in general, but about the very contexts in which it exercised its primary importance (e.g., Myers 2008, 2011; Sturdy Colls 2015; Theune 2011, 2015a, b).

In spring 1945, around 7,500 survivors, mostly women and children from the concentration camp of Ravensbrück, arrived in Malmö in southern Sweden (Leo 2006:512). On arrival they were given new clothes as their old ones, together with other belongings, were burned, out of fear of contagion. At the Kulturen museum in Lund there is, however, a collection of objects collected from and donated by survivors upon their arrival. Most of it is on permanent display in the exhibition Att överleva Röster från Ravensbrück (To survive - Voices from Ravensbrück) (also digitally displayed at http://www.kulturen.com/utstallningar/basutstallningar/att-overleva/; the artifact database is available at http://carl.kulturen.com/web/). At the University library in Lund there is, in addition to this, a large documentary archive, with material which was partly used in the post-war trials in Hamburg, including interviews committed to paper shortly after the arrival of the survivors in Sweden (http://www.ub. lu.se/en/voices-from-ravensbruck).

In this article the objects are investigated as expressions of resistance and sabotage, of memory and hope of a future, and of identity and human integrity. Close readings of interviews of Ravensbrück survivors further inform us about the gravity of the importance of material culture in the camp, produced under uncharitable living conditions.

\section{The Ravensbrück Material in Lund, Sweden}

Many of the survivors arriving in Sweden were of Polish descent. Zygmunt Łakociński (1905-87), at the time employed as a university lecturer in the Polish language at Lund University, volunteered as an interpreter. Together with Professor of History, Sture Bohlin, he organized a project where over 500 survivors were interviewed. Here, the interviews will be referred to by their number, as this is how the information is most easily traced, but the personal names of the interviewees are actually documented in the reports. The project was called Swedish Institute of Foreign Affairs' Polish Working Group in Lund (officially shortened PIZ; and this abbreviation is henceforth used in this article). PIZ was financed by the Swedish government and ran between October 1945 and November 1946.

The interviewees were encouraged to speak freely, but if needed they were to be guided by "orientation questions". The interviews were to be carried out as matter-offactly and objectively as possible and the interviewers were not to influence the interviewees in any way. Notes from a meeting of February 16, 1946 state that "[a]s unwavering principles [for the interview process] are established that: nothing is to be changed in the independent work of the witnesses, not in any way is the witness to be influenced while giving evidence" (Saml. Łakociński, Z, PIZ Vol. 44:6b, translated by the author; Rudny n.d.). The interviewees, accordingly, were to account for their experiences in a factual, non-emotional way, and their statements were to be confirmed by other witnesses. The interviewees were all of Polish nationality, but of varied ethnicities and religions, most of them Roman Catholic, but around 20 were Jews. 
The interviews constitute an important part of the Ravensbrück documentary archive in Lund, but the archive also contains materials that the survivors brought with them, such as maps, food recipes, calendars, glossaries, and diaries created in camp, as well as lists of who lived in which barracks, prisoners' transportation lists, and related material. This includes trial protocols, photos, press cuttings, and descriptions of the Lakociński project groups' working methods, and criteria for the interviews.

According to what was communicated to the survivors, personal items collected from them for cleaning, while they were undergoing delousing and medical treatment, were to be returned to them after they had been cleaned. This intention was, however, not always executed. Karin Landergren Blomqvist, who helped taking care of the survivors, remembers this with regret: "The clothes one was to take care of proved to be dirty rags, infested with lice, which were according to Swedish standards too worn down to be worth cleaning. The consequence was that it was all burned. Many survivors protested, but few dared to say why. They dared not believe we were fully without German influence. We had been too naïve and unsuspecting. In seams, hems and waistbands, many had with great effort and danger for life during internment in camp managed to save personal souvenirs and treasures. Now, when liberation was a fact, they lost these very last objects from their original lives" (Landergren Blomqvist 2002:29, my translation).

Łakociński, however, acting on his own initiative, collected some personal items and clothing which would otherwise have been burned. He did this out of the conviction that it might be valuable as documentation for the future of what had happened. The collected items were donated by survivors (several of them individuals actively involved in the PIZ-project, as for example Ludwika Broel Plater, see below). The previous owners of many objects are, therefore, known by name, as well as occasionally the original giver(s) and some of the objects' social contexts in camp, which is obviously not always the case with preserved items from concentration camps (compare with Knapp 2014:223). The Kulturen collection accounts for 202 artifacts in total, including a number of the typical striped jackets, some other worn clothing, and repeatedly patched shoes; various forms of labels bearing prisoners' numbers; smaller utility articles such as spoons, spectacles, and toiletries; medical devices such as syringes; and other utilitarian objects. Prisoners' number-labels, however, were actually from other camps and some objects are of uncertain origin.

Around one - third of the material is constituted by objects which could be classified as very personal memorabilia or intimate emotional items. Most of these have been painstakingly fabricated out of rubbish, chewed bread, or whatever material the prisoners could obtain, and might be classified as "trench art," as discussed by Saunders (2003:11), and later by, for example, Carr (2011:130) and Myers (2013:215). Similar objects as those preserved in Lund are present at the memorial museum in Ravensbrück. All in all, the documentary archive and the objects represent a material with great potential for extensive research, still largely untapped.

\section{The Concentration Camp of Ravensbrück}

In 1939, one of the largest concentration camps of the Nazi regime, especially for women, was erected in Ravensbrück circa $90 \mathrm{~km}$ north of Berlin. The camp was 
initially intended as a work camp, but in conformity with many other Nazi concentration camps, it changed character during the war and increasingly took on the form of an extermination camp. At the end of 1944, a gas chamber was built in which around 6,000 individuals were executed. In all, over 130,000 women and children from more than 20 nationalities, mostly Polish (ca. 25\%), German (ca. 20\%), Jews of different nationalities (ca. 15\%), Russian (ca. 15\%) and French (ca. 7\%), were taken as prisoners to the camp and its sub-camps (Morrison 2000:86, 253, 262; Saidel 2006:3-4, 23-25). In particular from 1944 and onward, the main camp housed a considerable number of children (Genest 2014:71). An unknown, but, it seems, large number were born in camp, although almost all of these babies died - or were killed - before long (according to numerous witnesses, e.g., interviews 10, 65, 109, 151, 163, 292).

Most women were used for heavy work, while others did not have special work. Being without work was not as favorable as it might seem, as it also meant scarcer food rations. Some women were sent to brothels, with the pretence of prompt liberation afterwards (which was not fulfilled), and some were used in severe medical experiments. These assaults are described in numerous interviews. Prisoners were also used to monitor activities or blocks of co-prisoners and thus became part of the camp administration. This resulted in complicated hierarchies amongst the prisoners, which could sometimes be a valuable resource, but which was also deeply problematic when it was misused at the expense of other prisoners. Furthermore, contradictions and conflicts between groups of different nationalities or ethnicities also existed (Eschebach 2014). One survivor recalls that "camaraderie did not exist. The nationalities fought each other. The fight for survival was most brutal and crude" (interview 6). Within national or ethnic groups camaraderie was, however, often strong.

Myers (2011) has discussed how ferociously materialistic the culture of the fight for survival might become within the concentration camp of Auschwitz, resulting in bargaining and black markets. This is also relevant for Ravensbrück, where individual prisoners' possessions were a source of conflict among them. The hierarchies and unequal conditions within camp meant that those with any possessions had to guard them constantly. In order to survive, the slightest possession was valuable either in itself or as something with which to trade. Therefore, naturally, many of those left without tried to acquire whatever they could (Morrison 2000:36, 142144).

The objects - or the material out of which they were fabricated - that circulated in camp originated from a number of sources. Until 1943 most newcomers were given a blanket, a toothbrush, a bowl, a wooden spoon, and clothes, but later, necessities needed to be stolen, bartered for, or "inherited" (interview 449; for comparisons see also Morrison 2000:120, 142-144, 163; Saidel 2006:103). When camp economy became more strained, prisoners were sometimes allowed to keep their personal clothes. During some periods, starting in 1942, some categories of prisoners were also allowed to receive parcels from home or from the Red Cross. Although valuables and some other contents were usually confiscated by the overseers (e.g., interviews 117, 235, 420; Morrison 2000:140-141), it meant circulation of material in camp. Those who worked outside camp or closer to the SS (e.g., in their office or in the camp kitchen) regularly "organized" the theft of food or other things which could be useful (e.g., interview 2, 32, 181; Morrison 2000:144). 


\section{Topic of the Study and Entrances for Understanding}

The material used in this study is not archaeologically retrieved. It has never been discarded or lost, but was saved and treasured and brought from camp at liberation. Also, unlike artifacts archaeologically retrieved from other camps, in the case of the Ravensbrück material in Lund we know for sure that it all consists of the belongings of former prisoners. Even if there were among the prisoners a hierarchical system where some of them also served as guards and overseers, which made the boundaries between prisoner and camp administration somewhat diffuse (compare with Leo 2006:488-493), we know that the objects in Lund were never the belongings of the uppermost camp administration. They might therefore serve as a valuable reference material in the analysis of excavated materials from concentration camps (c.f. Theune 2015b).

I have been able to analyze all interviews which have, up until September 2016, at one stage or another (with somewhat varying rigor), been translated from Polish to either English or Swedish. One hundred seventy-three interviews have thus been accessible to me. Of these, a little less than $25 \%$ have recently been professionally translated in an ongoing project, run by the University library, to increase the availability of the material.

The present study is related to the field of conflict archaeology or, more specifically, the archaeology(ies) of internment, as the material might be best understood in comparison with other materialities' of conflict or of internment (cf. Casella 2011; Moshenska 2013; Myers and Moshenska 2011). It springs out of the tensions between suppression and resistance, obliteration and acts of memory, uniformity, and individuality, and the objects themselves are material traces of the various coping strategies employed by the prisoners of Ravensbrück (cf. Mytum 2013).

The value of material culture and the materiality of objects can reside in their material, the fabric or fabrication, but also in them being inherently bound to a special person, a place or an event, or a combination of these (cf. Hurdley 2013:219). In their discussion of physical military or civil remains of human conflict (aka matériel culture), Schofield and colleagues recognize and emphasize the "very explicit and often intimate terms of the materiality of ... wars and what it represents in terms of human experience, including personal tragedy and loss of life" (Schofield et al. 2002:2). The objects from Ravensbrück at Kulturen are indeed such matériel culture of a most intimate kind, in many respects distanced from the larger structures and more manifest remnants of war. Simultaneously they clearly mirror the political agitations taking place outside the camp by (for example) the often-recurring colors of the flags of the prisoners' nationalities, which signal that these loyalties were just as present and potent within the barbed wires as outside.

The objects can be understood as powerful expressions of human agency; agency against all odds. Life-affirming material expressions, as a paradox to the lifesuffocating physical context of these expressions, are relevant for the understanding of the existential conditions of the prisoners. It is not, needless to say, to be understood as an attempt to in any way diminish the horror of the Nazi system or the sufferings of those smitten by it. It is to be understood as recognition of their sacrifices, and equally as recognition of their struggles and capacities by highlighting the objects which are the results of their struggle for survival, for integrity, dignity, and a sense of self-worth. It is 
a poignant insight that these values were so fundamentally vital to the prisoners, that the scarce and miserly bread rations were often used for buying on the camp black market, or even fabrication, small items helping to uphold these values. Food intended to preserve some physical strength was thus - directly or indirectly - transformed into items intended to preserve mental and emotional strength (cf. Carr 2011:130).

As a scholar studying the material culture of the past, one is constantly struggling with the awareness that the answers we can distill are predestined by the questions we ask. As already reflected upon above, the context of obliteration in the concentration camps stretches and challenges the limits of the interpretation of material culture. As a consequence, shared with studies of other forms of "difficult" or "dark" heritage (e.g. Harrison 2013:192-196), it becomes all the more dishearteningly clear that the questions not explicitly asked are at risk of remaining unanswered, and the dark corners, un-illuminated.

The issue of absence in history or archaeology has recently been discussed by Fowles and Heupel (2013). As they rightly observe, we have a tendency to overlook the gaps in our pursuit of information in what is there and they note that "there is no comparable enthusiasm within archaeology for absenting presence. Absence is inevitably treated as a problem to be solved." The gaps are to be filled in. Also, within heritage studies, there is an increasing awareness not only of difficult or dark heritage, but of "absent" heritage; what is not visible, what is not chosen to be preserved and commemorated, and which stories are not told and remembered (Harrison 2013:182-192).

The material discussed naturally represents only a small group of all the prisoners who passed through the camp in Ravensbrück. Most prisoners did not survive, and only a few were chosen to be sent to Sweden on the White Buses, and survived this trying transition. Relatively few of these agreed to be interviewed and/or donated their last belongings relating to the camp to the project of PIZ. The "absence" in the material for this study is therefore, in many ways, far greater than the "presence." This is also painfully immanent in the character of the subject as such. The voices not heard are far more numerous than the ones heard. The saved treasures are easily counted and exceedingly rare, considering the vast number of individuals passing through the camps. "Those with the most horrid experiences did not survive," as Levi (1989:83-84) has so emphatically and irrefutably expressed. Being well aware of this mutilation, however, serves more than anything as a powerful and empathic incitement for mindful attention to what is left, to those who can still be "heard."

In the following I choose more explicitly to discuss three themes, namely, material culture as expressions of resistance and sabotage, of memory and hope of a future, and of identity and human integrity. The choice to address these particular perspectives springs from recurring statements by interviewed survivors about the meanings of objects, which signal that these were indeed important values connected to them. However, the three themes are of course tightly intertwined and intimately connected. Many - or even most - of the objects mentioned would certainly fit into several categories. Likewise, the themes addressed do not claim to capture the full complexity of meanings harbored by the artifacts. In the end, the main concern for the prisoners was, naturally, always the struggle to stay alive, to stay human; something to which I return in my concluding remarks. However, resistance and ways to uphold memory and identity were important coping strategies in this struggle. 


\section{Resistance and Sabotage}

Resistance and protest can be powerful even when executed under clandestine circumstances and with minimal means. Knapp (2014) draws to attention how definitions of resistance historically have had male connotations and often been defined as armed resistance. However, broader definitions recognize also other forms of resistance; forms which, Knapp suggests, will in future perhaps be recognized as at least as important and powerful as armed forms of resistance. These other forms of resistance have often shown to be performed by women and to include often small scale and more discrete forms of actions such as the very coping strategies which will be discussed in this paper: consolidating social bonds, organizing care for children and the weakest, shielding memories and personal integrity, and taking care of personal hygiene and clothing as well as seeking intellectual, esthetic, and emotional stimuli (Knapp 2014:226-231, but also Leo 2006:494-495). Interestingly, according to Knapp (2014:226-231), these strategies were not always recognized as acts of resistance by the Ravensbrück prisoners themselves. They, obviously, had been brought up with the male definition of their time. They did, however, recognize their actions as "sabotage" - a term used by camp administration for prisoners' behavior or actions which were not sanctioned.

One strategy of resistance was tending to the physical needs - and thereby increasing chances of survival. Most important was to have clothes and shoes, to protect oneself from "the "extremity of nakedness" (cf. Myers 2011:80). This was sometimes so acutely needed that it was prioritized even above food. One survivor recalls: "I cared mainly to get more clothes; it was cold and I had no underwear. I bought underwear and stockings by paying with bread. For a fortnight I ate no bread, exchanging all I got for clothes" (interview 50). Several other interviewees tell similar stories (e.g., 42, 449). Another way of getting clothes or a pair of shoes was to try to "inherit" them or to take them off a dead person (survivor interviewed in Saidel 2006:143). In the collection in Lund are some pairs of shoes, made in camp, and then repeatedly mended and patched (KM88824, KM88871). These, however lumpy and clumsy, must have been very valuable. There are also a pair of leather halfsoles, even in their fragmentary state treasured and saved (KM88872). Almost as valuable to its owner was a threadbare cotton handkerchief (KM89009), perhaps to protect a shaved head against the scorching sun or biting cold during work outdoors or during Appell, as described in interview 50: "The line-ups were dreadfully long, winds tore off our heads. I was hairless, and one was beaten for wearing head wraps."

An imperative aspect of the treatments of the prisoners in the Nazi camps was to break down their intellectual strength, human integrity and dignity, and their ability for resistance.

Typical of that first period was the thorough application of German "educational methods" with respect to the conquered nation. Above all, these consisted of killing a person's individuality and her belief in her own strength, loss of ambition, and loss of her desire to respond to being offended. The program also involved the fomenting of hatred between classes and ethnic groups, and the encouragement of suspicion and informing (interview 420).

Various activities to prevent mental and intellectual breakdown was, therefore, a major form of resistance. 
To stimulate intellectual activity through teaching was also a potent form of resistance, which was, as it seems, mostly operated by members of better organized groups of political prisoners and among the Poles. Survivors recall how the long hours at Appell or the free time at night were sometimes used for this: a teacher would stand in a middle row, and those behind and in front of her would listen to teaching about Poland, art, history, literature, and other subjects. They would have practical exercises, such as drawing maps or studying the constellations of the starry sky. Those who were teachers by profession sometimes wrote down school books from memory, on whatever paper could be found, and taught the children of the camp (see also interviews 235, 420, 449, as well as survivor interviewed in Morrison 2000:166-167; Saidel 2006:62-63). There are several hand - made miniature books, made out of whatever material was available - cardboard, small scraps of paper, often covered with some kind of fabric, with meticulously lettered poetry, proverbs, or glossaries.

One example is a tiny book measuring only $3.3 \times 3.3 \mathrm{~cm}$. Great care has been taken that it should resemble a properly bound book. On the front of the second sheet it says "Od Staszka i Lilka" (From Staszka and Lilka) and "13-III-1944 Ravensbrück" in neat handwriting. The book contains Rudyard Kipling's very powerful poem "If" (in Polish "Je'sli...") about keeping your integrity, not giving way to hate, to find power and the will to go on when there is nothing left. The poem is no doubt carefully chosen, written down from memory, to give strength.

Resistance could also be about transferring information, within camp or across the camp borders. In the collection in Lund there is a small flat bag (KM88877, Fig. 1), sewn out of dark cloth, with the initials LP embroidered on the cover flap. It was a gift to Ludwika Broel Plater, who from her position as a worker at the knitting factory helped many co-prisoners in various ways (interview 65). In camp, the small bag was carried close to the body and was used to deliver secret messages. It was therefore called "the sabotage bag." Plater received many gifts, including a small white rabbit with red eyes, beautifully carved out of a white plastic toothbrush handle (KM88992). The rabbit symbolizes the medical guinea-pigs (in German "Kaninchen," "rabbits") of the camp, among whom the donor Zofia Hoszowska was one. Plater was a senior lady,

Fig. 1 The "sabotage bag" (KM88877), ca. $19 \mathrm{~cm}$ high. Photo: Viveca Ohlsson, Kulturen

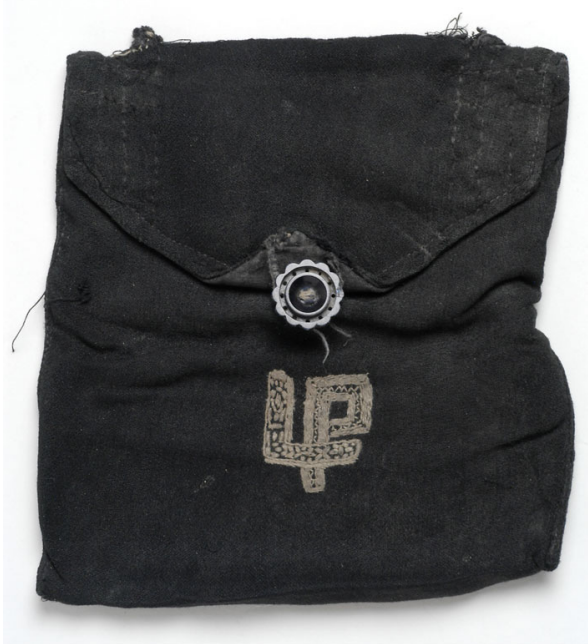


a Polish duchess, who was notable after her arrival in Malmö for always being very friendly (Landergren Blomqvist 2002:47-48). She became one of the interpreters in Łakociński's project, which is why the collection contains several items which belonged to her. According to an informant, Lise, cited in the Kulturen exhibition, dolls were sometimes used to hide secret messages. Perhaps a little child or young girl increased the chances of successfully passing messages because of her more innocent appearance.

One way to morally strengthen one's co-prisoners and preserve a sense of human value, and in that way increase the chances of survival for both her and oneself, was to help each other in various ways and to give small gifts in gratitude. Many of the objects in the collection are gifts in thanks for services (e.g., interview 181, Fig. 2). Small but exquisite jewellery and charms in the form of animals or flowers were formed with great skill out of buttons, toothbrush handles, small pieces of yarn and cloth, cardboard, chewed bread, and whatever could be obtained (e.g., interview 420).

Fig. 2 Sprig of the Lilly of the Valley, carved out of plastic (KM88840), ca. 3 cm. Photo:

Viveca Ohlsson, Kulturen 
But to own something private which was not approved of by camp administration, and any measures taken to get hold of it, can - in the forms brought forward by Knapp (2014) - be seen as acts of resistance and sabotage. Actually the very act of making something into a material representation added to the power of it in terms of resistance, as it meant subjecting oneself and others to danger, risking reprisals, severe punishment, and even death (e.g., interview 84, 143, 420; Leo 2006:495-496). One survivor recalls: "The smallest infractions were elevated to the level of 'sabotage,' which brought the highest possible sentences: whipping, the bunker, and even execution by shooting. For making toe-warmers with camp wool for her stockings in the winter, a prisoner would get 25 blows and two weeks in the bunker" (interview 420).

\section{Memory and the Hope for a Future}

If we go back in time, traditionally within archaeology, memory has mainly been discussed to refer to social and public memory, often in relation to larger structures and monuments. This form of memory can be said to be directed and manifested outward with, at least partly, the purpose of influencing how others remember us or our group (society, nation), and to create a common memory to form group identity. Today, however, we also increasingly seek to identify, study, and understand memories on a more personal, individual, or other small-scale level. These memories can be said to be more intimate, with importance mainly for the individual or the family/small group, in creating identity. This form of memory certainly also has a profound social dimension, but in comparison it is more directed inward toward the self, the domestic sphere, or smaller social context.

Spitzer (1999:92) has discussed the importance of the animating power of "nostalgic memory" for Central European WWII refugees in Bolivia. Rather than dismissing nostalgic memory as simplistic or escapist, he recognizes that "by establishing a link between a 'self-in-present' and an image of a 'self-in-past,' nostalgic memory also plays a significant role in the reconstruction and continuity of individual and collective memory." Nostalgic memory can be employed in efforts to try to distance oneself from a real and difficult present and, by a selective emphasis on positive contents of the past, and suppress it with more life-affirming memory. Recalling (chosen ingredients of) the past may furthermore function as a means to try to evoke a future resembling that past. Memory thus serves to "remember the self," in "a continuous process of "remembering, of putting together moment by moment" (King 2000:175), and so help (re-)construct identity in an ongoing attempt to connect to the past. It can be used to solder past, present, and future into an interrupted and discontinuous personal or collective narrative (King 2000:3-8, 29, 175).

In order to get strength and motivation to struggle on in camp, it was important to remember, to re-member oneself, and to commemorate the past. But not only to remember, but to make the memories invoke the future. In the Ravensbrück documentary archive in Lund there are several geographical maps. Some seem to have been drawn from memory, whereas others are transferred onto thin paper from an original. These latter are often of great detail, and might have been used for educational activities in camp, and might also have had an intentional use in the case of liberation or escape. But perhaps drawing them also meant visiting the various places in memory, and in 
either case it must have housed a hope of escaping the barbed - wire existence in a hoped - for future.

Many small objects in the collection bear clear connotations to the native environments of the survivors. The colors used for a book cover or small knitting might be those of a national flag (e.g., KM88940, KM88941), and small charms might take the form of traditional folklore from a certain region (e.g., a bundle of small charms in traditional Zakopane style, KM88944, Fig. 3, or the edelweiss flower). Small books contain poems, mottos, and proverbs, things to memorize and perhaps repeat to oneself during long hours at Appell or slave labor.

In the starving conditions of the camp, the memory of lush food could also provide strength. Numerous scribbled down recipes of delicious food on small pieces of paper, parts of newspapers, cardboard, and the like in the Ravensbrück archive in Lund are traces of this. One survivor recalls that at night, when everyone was lying on their crowded bunks, one could hear whispers of recipes of delicious cakes, and the like, reveling in a lot of those rich ingredients which were never present in the camp (interviewee cited in the Kulturen exhibition, also compare with Morrison 2000:114115; Saidel 2006:5-6). One survivor said: "We were all constantly hungry. Thus, unsurprisingly, our main topic of conversation was all things to do with food" (interview 38).

Another form of memory is commemoration connected to certain dates, but also memory to keep track of time. There are several calendars, bound into carefully made books, in which important dates are marked, as well as what might be the death dates of significant co-prisoners, perhaps family members or friends. Such dates are marked with what I interpret as prisoners' numbers or with personal names. The calendars thus played a role in commemoration. But there was also another aspect of memory, in which the many calendars take on another and more fearsome meaning. According to Apolonia, a survivor cited in the Kulturen exhibition, the camp guards used to ask individual prisoners what date it was, as a means to check their intellectual status. If a prisoner could answer correctly it increased her chance to survive for yet some time. If she could not, it might be used as an argument to liquidate her.

Fig. 3 Charms tied together with a string (KM88944), each measuring ca. 3-4 cm. Photo: Viveca Ohlsson, Kulturen

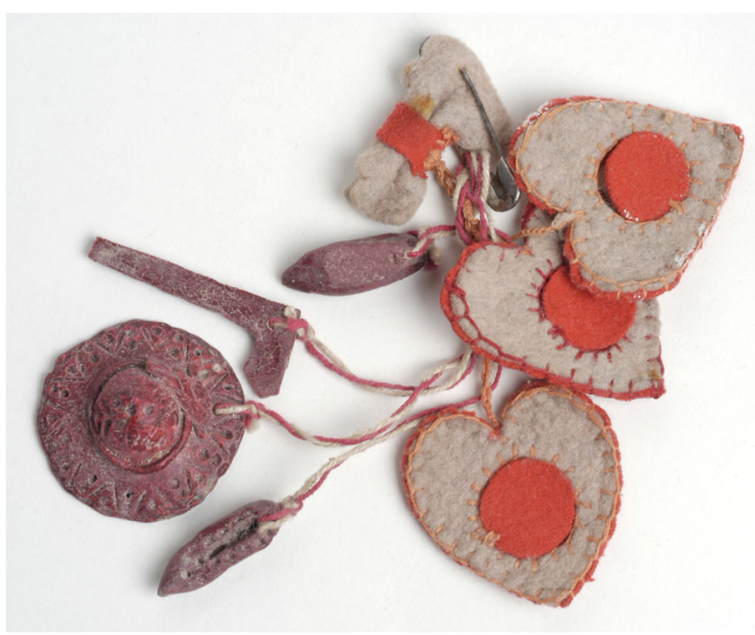


One aspect of memory often discussed in connection to Holocaust research and psychology is forgetting (e.g., Assmann 2011:396-400, 2016). Within cognition research one speaks of false or more or less suppressed memories (Wagenaar and Groeneweg 1990). Moreover, memory/forgetting and identity are intimately bound. To remember is both an individual process and a social, collective process; and these two processes intimately interact (Bergson 2004; Halbwachs 1992; Middleton and Brown 2005). It is not possible to discuss this complex matter further within this article, but while the artifacts from Ravensbrück, as well as the interviews, bear witness to the vital importance for the prisoners while in camp to remember anything which could be appreciated as normal as originating outside the hell of the camp, it is also clear that after liberation, forgetting the time in camp was equally vital to many. It seems, from reading correspondence and meeting memos from PIZ, that a lot of survivors were not willing "to, in their minds, return to the horrible past" (memo dated February 16, 1946, Saml. Łakociński Z, PIZ Vol. 44:6b). The PIZ staff had some difficulties recruiting interviewees. Many survivors just wanted to forget in order to have the strength to move on, to create new and lighter memories, as is a well-known phenomenon among Holocaust survivors. Those who did agree to be interviewed were individuals who found it bearable and possibly also helpful to retell their experiences, as a way to let go of it. Perhaps donating what small memorabilia they had left to the PIZ project was also an expression of a wish to leave the time experienced in camp behind?

\section{Identity and Human Integrity}

In her discussion on Home, Materiality, Memory and Belonging, Hurdley (2013:19) has suggested that "assemblages of people, things, talk and architecture, among others, work together in performing and ordering the social." It contributes to the formation of the identities of the individuals in these social settings. The filth, the lice, the crowdedness and the stinking smoke from the crematoria, the brick walls and barbed wire, the worn down bodies and the fear of death of the still living, were all acutely real in the camp, and it contributed to the (de)formation of the identities of the imprisoned. While the prisoners' identities desired and aimed at by the Nazi ideology and the camp administration was that of anonymous numbers, of dehumanized sources of manpower, there were, as pointed out above, strong movements within the prisoners' groups to counter this.

Every item, however modest, that could contribute to the resistance against dehumanisation and de-individualization in a context where the Topographie des Terrors of the camp aimed to suffocate all such, was therefore essential. It is in this extreme context we should understand the significance of the most unpretentious things in the collection, such as a dried edelweiss flower, a couple of spikes of grain, half a hazelnut shell twice perforated so that it could be attached with a thin thread (KM88985, KM88983, KM88984, KM88841). One survivor has said that "[h]aving something of your own was wealth - a treasure" (cited in the Kulturen exhibition).

Educational activities in the camp have been mentioned above as forms of resistance, but these activities were probably equally important for matters of identity. The educational activities, as well as the books, maps, glossaries, etc., used in these activities were often performed by professional teachers, who in this way were allowed 
to keep some of their professional identities. Also professional artists, to some extent, used their skills in camp, such as drawing/painting, creating poetry, and singing (e.g., interview 17, 235, 420).

Religious expression was forbidden by camp administration. This was of course a major offence to the integrity of religious individuals, but prisoners sometimes found ways to get around the ban and for many this was an important source of strength. Religious (Roman Catholic) artifacts, mostly rosaries, make quite a large group in the collection in Lund. One must have been fabricated in camp out of seeds and/or bread crumbs (KM88960), while others might have been brought there from outside (KM88919, KM888920, KM88959, KM88962, KM88963, KM88964, KM88966). There are also home-made crucifixes made out of iron screws, screw-nuts, plastic, and carved wood (KM88842, KM88960, KM88965, KM89012).

Jewish religious symbols are not present in the material in Lund. The Jews interviewed by Łakociński's team were a minority. Moreover, conditions for them in camp were much more difficult than for other groups; to practice religion was even more of a risk. As Morrison (2000:72) points out, "Jews were rarely given desirable work assignments, they were almost never appointed to positions as prisoner officials, and their barracks were the first to be overcrowded. They were, in short, prevented from becoming part of the camp's power structure, and as such, they lacked the wherewithal to trade favors and 'scratch backs' which might have improved their status." This also meant that they did not have much opportunity to acquire any pieces of material culture, as this was either smuggled from work assignments or traded for in the reciprocal system among the prisoners. The Nazi efforts of dehumanization and deindividualization thus struck certain groups of prisoners, such as Jews and Sinti, harder than others (compare with Genest 2014:86).

In the Kulturen collection there is, however, a small crucifix made out of plastic (KM88961), which is especially interesting, as it is the result of generosity across religious identities. It was a gift from the Jewish women in the knitting factory, given to Ludwika Broel Plater in gratitude for her consideration for them.

Religious holidays were in simple but powerfully symbolic ways sometimes celebrated. Sermons were held and Christmas gifts were at least in some years made and shared (e.g., interviews 10, 65, 151, 163, 420). For example, a small $(4 \times 4 \mathrm{~cm})$ heart made out of a red and blue cotton jersey, with intricately foldable pages inside, which says in Russian "Dear Ketju! I congratulate you on the holy birthday and wish in a near future to be home and meet again my beloved little mother and all my friends. 24, 12 Vera" (KM88837). In 1944 in particular, when a large number of children lived in the camp, great efforts were made to give them small presents (Morrison 2000:267-268; Saidel 2006:70). Some of the dolls preserved in the collection in Lund might have their origin in that last Christmas spent in camp, as might some other figures of varying character - a colored woman wearing a dress, one wearing trousers, a maid churning butter, a clown, a Santa Claus (KM88832 (Fig. 4), KM88833, KM88880, KM88881, KM88882, KM88935, KM88936, KM88937, KM89026). Some dolls are simpler, some more elaborate, but for all of them great care has been taken to find suitable materials for the skin, hair, face, and clothes. Faces are painted or embroidered and sometimes even sculptured, perhaps out of clay or chewed bread, under the fabric used for skin. Neat clothes and miniature shoes have been sewn, knitted, and embroidered. Most of the dolls are small and were easy to hide, but a couple of them are larger. 
Fig. 4 Doll (KM88832), ca. $26 \mathrm{~cm}$ high. Photo: Viveca Ohlsson, Kulturen

To be a child in camp was evidently very hard and chances for survival were small (Morrison 2000:273). The material evidence of the recognition of and concern for the very childishness and the childish needs of the children living there - their identities as children - are therefore extremely moving. It seems to have been a fairly well developed practice that children without mothers or other older relatives of their own in camp were "adopted" by other women, so called camp mothers (lagermütter), who paid special attention to them and made efforts to increase the child's chances for survival (e.g., Leo 2006:494).

Great creativity and skill can be observed in how small charms, jewellery, elegant slippers, wallets, and clutch bags were carefully and with great skill carved out of plastic or formed from, for example, cardboard, wool, cloth, straw, or chewed bread (KM88836, KM88840, KM88923, KM88924, KM88926, KM88839, KM88934, KM88938, KM88939, KM88940, KM88941, KM88944, KM88955, KM88967, KM88986). A group of three amber-colored objects - a miniature sword, an arrow pointed wand with hearts and flowers, and a row of tulips are known to have been carved out of a toothbrush handle (KM88945, KM88946, KM88947). A small aluminium heart has a faint engraving punched in Polish: "Beloved little mother, Hanka" (KM88943, Fig. 5). All these objects seem to connote identities which have to do with friendships and relationships such as mother-child, and with what I would categorize as aspects of femininity and womanhood. A very important function of these things had to do with (re)building and maintaining identity.

Also, of course, inscribing a personal name (as the name Hanka on the aluminium heart, and several other examples of names of giver and receiver mentioned in the 
Fig. 5 Heart with carving

"Beloved little mother, Hanka" (KM88943), ca. $5 \times 5 \mathrm{~cm}$. Photo: Viveca Ohlsson, Kulturen

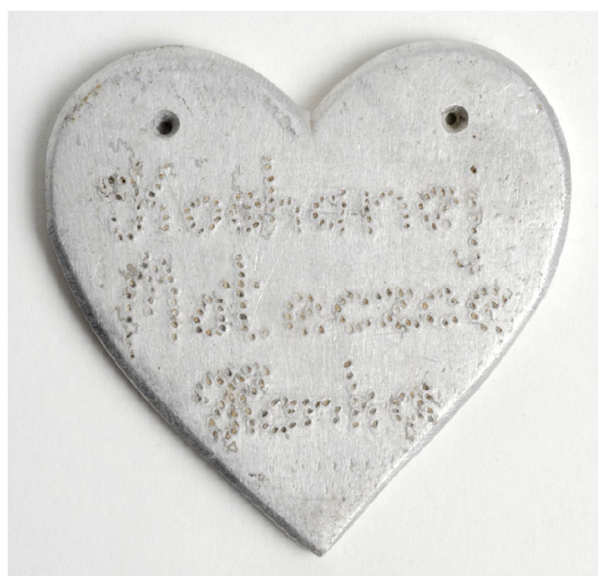

previous text) was a very clear and powerful statement of personal identity and against being reduced to a prisoner number.

An important part of identity, which was perhaps emphasized in wartime and in exile, was national identity. Many of the women imprisoned in Ravensbrück were political prisoners, engaged in (or related to persons engaged in) political activities in their homelands. Among the objects are, not surprisingly, paraphernalia of nationalistic character. There are Polish military buttons, badges, and memorial coins (KM88948, KM88949, KM88932, KM88931), as well as flags and pennants in the Polish and Belgian colors (KM88927, KM88951, KM88996, KM89014). But there are also handmade objects, similar in character to the charms and miniature objects mentioned above, which are made in the colors of national flags (KM8894, KM88941). To maintain national and ethnic identities within the camp seems to have been important and, as already mentioned, many of the interviewees witnessed antagonism between groups with different national or ethnical identities. Prisoners in camp were no betteror worse - than people outside.

A couple of objects in the Ravensbrück collection are puzzling: two embroidered badges in the form of shields, the kind you might buy as souvenirs when on vacation, to attach to a jacket or a bag (KM88873, KM88874, Fig. 6). They were made in camp or shortly after liberation, and show scenery and symbols from the camp. One mentions block 13, the other block 17, and the latter also the date of liberation. How are these to be understood? One survivor, a girl who spent time in the camp with her mother, recalls: "After return to RAVENSBRÜCK I landed in the good block No 17; block management was good; while my mummy got to block No 27 and suffered drudgery there" (interview 322).

Was it comparatively good to identify with blocks number 13 and 17? Carr (2011:138) discusses the practice of wearing barbed - wire brooches in the camp of Biberach, and suggests they might either have been "statement[s] of defiance: 'interned but proud' against their captors" or the results of a wish "to turn something that was hated and ugly into something that was desired and attractive." A couple of V-shaped features in the upper left filed of the badge in Fig. 6 have previously been interpreted as birds. But might they also be read as discrete V-signs as in V-for-victory; the campaign which spread among occupied peoples of Europe (Carr 2011:138-139)? Either way, the 
Fig. 6 Embroidered badge from block 17 (KM88874), measuring ca. $8 \times 9.5 \mathrm{~cm}$. Photo: Viveca Ohlsson, Kulturen

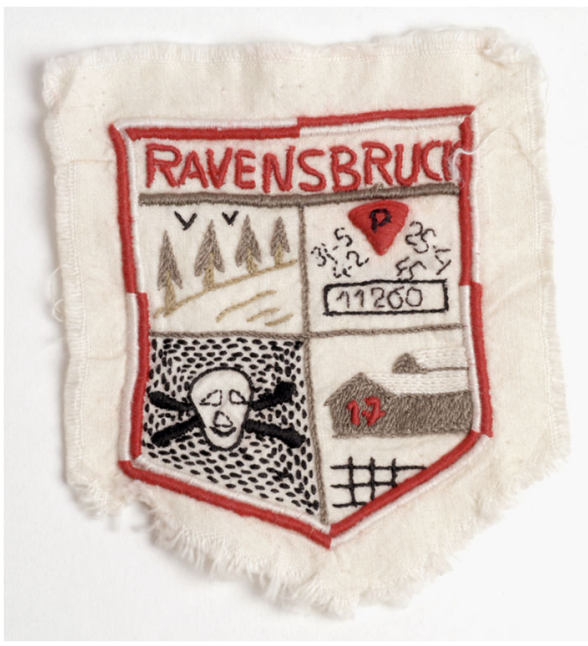

badges from Ravensbrück constitute intriguing examples of how identity can merge with resistance and perhaps even the incorporation of elements of the oppressive power in order to disarm them.

Another side to the issue of identity is of course disguised identity. "Selection" was a recurrent agony for the prisoners, when those too old, ill, injured, or worn down to work were selected for the Jugendlager (a side camp generally known to be a place from which few ever returned) or, later, the gas chamber. In order to avoid being selected it was crucial, if possible, to disguise any symptom which could signal enervation. One way to do this was to color the hair and the cheeks. A couple of lipsticks (KM88878, KM88879) are said by an informant to have been used by groups in block 29 in camp to color the cheeks when they were threatened by selection some time in 1945 (http://carl.kulturen.com/web/object/186458; http://carl.kulturen. com/web/object/186459). But also at arrival in Malmö after liberation, lipsticks and make - up powder were among the most desired objects among the survivors, because of what it symbolized in aspects of human worth, and of femininity (Landergren Blomqvist 2002:39; compare with Grant 2009:37). It represented the opposite to the camp where they in so many ways had been "deprived" of their private bodies.

The camp administration identified prisoners by numbers, but it is evident from the interviews that many women did not (or would not) by then recall the number they had worn. But in almanacs made and kept by prisoners in camp, co-prisoners sometimes seem to be referred to by their numbers. One example is an almanac which covers the spring of 1945 with the last note on April 25, the day of liberation of the camp. On February 3 the death of a person (?) is marked, not only with a personal name, but also with what seems to be this individual's number, 51,630. Why was that? For some reason it was important to the owner of the little almanac to remember the number this woman had been given by her oppressors, perhaps to later report? Lists of prisoners, of transportations, medical experiments, and deaths were kept by the prisoners. But numbers could also be used as forms of disguise. One survivor (interview 180) describes how she used the prisoner number identities of dead prisoners when she was performing actions of "organizing" food or other necessities to help co-prisoners. 
Wise from experience she never used her own number to do such acts of resistance, because if she was caught with a fake number, the guards would not be able to trace her, and so she could hope to avoid punishment.

\section{Concluding Remarks}

In this article I have approached a number of items once belonging to Ravensbrück prisoners as expressions of resistance and sabotage, and suggested their importance in relation to memory and the hope of a future, identity and integrity. But much of it can really be boiled down to questions of identity and strategies to survive. As already mentioned, various kinds of intellectual, cultural, and religious resistance were extremely important. It constituted the strongest forms of resistance, because destroying people by annihilating exactly these qualities was a primary strategy employed by the Nazi ideology and camp administration. Engaging in related forms of activities thus helped keep hold of an identity and one's integrity and sense of dignity, which was crucial in order to stay alive and stay sane in the camp.

But why was it important to support this with material culture, considering the risk it meant if discovered by guards, which could lead to severe punishment? Objects might also so easily be lost (stolen, dropped, confiscated), and if or when that happened, what consequences did that have for the struggle to nurse one's dignity and identity? Would it not have been a less vulnerable method to stick to the immaterial carriers of identity?

A material object is concrete and thus has a kind of permanence which could give support when intellectual and emotional strength failed. A human being is constituted not only by intellect and emotions; she is also body. And related to our body, our material self, are other forms of material culture, almost as if it connects our inner self (with emotions, norms, values, cultural or other) to our outer self (body). To own something, anything, seems to have been a very important general aspect of being human. In camp, any possession could take on a very strong symbolic value, connected to a number of truly existential variables, such as recognition and remembrance of the world from which one came, a sense of belonging, of beauty, vanity, culture, and intellectual capacity, religion, humanness, friendship, and other loving relationships.

It was not only possessing something that was valuable; also making things was significant, as certified by several survivors (e.g., cited in the Kulturen exhibition), in that it meant distraction from the surrounding reality. It was a way "to consume time and mentally evade barbed wire" (Carr 2011: 140). As mentioned earlier, during some periods certain groups of prisoners were allowed to receive packages from home or from the Red Cross. One survivor recalls: "The whole time I was regularly receiving packages from home and it was thanks to those packages that I recovered from all those illnesses" (interview 189). But far from everyone received any packages or letters or anything else to keep up the spirit and will to live. A Jewish survivor, for example, comments that "Jewish people were taken with their entire families and wiped out totally. ... The Jewish people didn't have any 'back home.' ... Imagine getting a letter from home. It would be enough to keep you wanting to live, no matter how starved you are, to get a little package" (cited in Saidel 2006:144-145). 
The small and seemingly unpretentious objects brought to or made in camp were of paramount importance for supporting memory of home, of the world as it used to be, the world which was not the camp. These memories were essential building stones in the (re)creation of identity for individuals as well as for groups. The aspects of identity most clearly expressed in the Ravensbrück material relates, I would argue, to a large degree to the affectionate social sphere, and the roles of family relations and friendships. It expresses gender (woman, child), physical appearance, intellectual capacity and integrity, national/political, cultural and religious background, and loyalty, emotions, and esthetical joys. Remembering those qualities might also have served as an invocation that one might come to be, once more, in a future beyond the hell of the camp.

It is possible that the specific character of the Ravensbrück material, with its large proportion of gifts of beauty and affection, is due to Ravensbrück being principally a women's camp (compare with Leo 2006:494). There were, as mentioned, tensions among the prisoners, among hierarchical levels, ethnic groups, and nationalities. Some constellations managed to keep up some support systems, but it is also natural that the fight for survival brought forward selfish behaviors. On the other hand, the giving of gifts in return of services, sharing recipes and the like, helped the women fortify each other and thereby increase the chances for survival. In this, the gender aspect of the prisoners' identities in Ravensbrück might have played a significant role. As several scholars already mentioned have noticed, this system of reciprocity seems to have been unique for women in concentration camps, with only relatively few examples among male prisoners. And it might actually have increased survival rates in women's camps (Leo 2006:494). The gendered origin of the objects of the collection in Lund most certainly has shaped its composition and character.

When compared to archaeologically retrieved artifacts from other camps (e.g., Mauthausen, Sachsenhausen), similarities as well as differences can be observed. It should be noted that many of the prisoners in Ravensbrück had been interned in several other camps. Prisoners were transported between camps by foot or by train, within an extensive logistics system. Many of those still alive at the time of liberation had been in Ravensbrück for only a limited period of time. Differences between material from Ravensbrück on the one hand and Sachsenhausen and Mauthausen on the other, therefore, probably partly have their explanations in the methods in which the materials have been collected. Another explanation might be that the Ravensbrück material has an indisputable affiliation to victims rather than oppressors. However, I argue that gender explains the larger proportion of objects related to the domestic sphere and to reciprocity.

The objects from Ravensbrück may seem modest and inconspicuous at first glance, but as we have seen, this is deceiving. They were essential and served as ersatz items for another life in absurd circumstances. When bereaved of everything, material culture can carry powerful symbolic connotations, making it truly vital.

Acknowledgments I would like to thank Professor Claudia Theune for sharing with me her databases on material from the camps of Mauthausen and Sachsenhausen. Thanks Mats Roslund, Department of Archaeology and Ancient history, for support. Thanks Thomas Bergqvist Rydén for reading my manuscript in a late stage. I also thank Tomasz Lesniak and Håkan Håkansson, Lund university library, and Karin Schönberg, Kulturen, for assistance and access. 
Open Access This article is distributed under the terms of the Creative Commons Attribution 4.0 International License (http://creativecommons.org/licenses/by/4.0/), which permits unrestricted use, distribution, and reproduction in any medium, provided you give appropriate credit to the original author(s) and the source, provide a link to the Creative Commons license, and indicate if changes were made.

\section{References}

Assmann, A. (2011). Cultural Memory and Western Civilization: Functions, Media, Archives, Cambridge University Press, Cambridge.

Assmann, A. (2016). Shadows of Trauma. Memory and the Politics of Postwar Identity, Fordham University Press, New York.

Bergson, H. (2004). Matter and Memory, Dover, New York.

Carr, G. (2011). Engraving and embroidering emotions upon the material culture of internment. In Myers, A., and Moshenska, G. eds., Archaeologies of Internment, Springer, New York, pp. 129-145.

Casella, E. C. (2011). Lockdown: On the materiality of confinement. In Myers, A., and Moshenska, G. eds., Archaeologies of Internment, Springer, New York, pp. 285-295.

Cole, T. (2013). The place of things in contemporary history. In Graves-Brown, P., Harrison, R., and Piccini, A. (eds.), The Oxford Handbook of the Archaeology of the Contemporary World, Oxford University Press, Oxford, pp. 66-81.

Eschebach, I. (ed.) (2014). Das Frauen-Konzentrationslager Ravensbrück. Neue Beiträge zur Geschichte und Nachgeschichte, Metropol, Berlin.

Fowles, S., and Heupel, K. (2013). Absence. In Graves-Brown, P., Harrison, R., and Piccini, A. (eds.), The Oxford Handbook of the Archaeology of the Contemporary World, Oxford University Press, Oxford, pp. $178-191$.

Genest, A. (2014). Die Gruppe der polnischen Häftlinge: Geschichte und Erinnerung. In Eschebach, I. (ed.), Das Frauen-Konzentrationslager Ravensbrück. Neue Beiträge zur Geschichte und Nachgeschichte, Metropol, Berlin, pp. 67-93.

Grant, L. (2009). The Thoughtful Dresser, Virago Press, London.

Halbwachs, M. (1992). On Collective Memory, University of Chicago Press, Chicago.

Harrison, R. (2013). Heritage. Critical Approaches, Routledge, London.

Hurdley, R. (2013). Home, Materiality, Memory and Belonging. Keeping Culture, Palgrave Macmillan, New York.

Kelly, S. (2010). In the sight of an old pair of shoes. In Hamling, T., and Richardson, C. eds., Everyday Objects. Medieval and Early Modern Material Culture, Ashgate, Farnam, pp. 57-70.

King, N. (2000). Memory, Narrative, Identity: Remembering the Self, Edinburgh University Press, Edinburgh.

Klang Eriksson, E. (2002). En tallrik minnessymbolik. In Tingsligheter, Kulturen, Lund, pp. 132-141.

Knapp, G. (2014). Widerstand und Resistenz. In Eschebach, I. (ed.), Das Frauen-Konzentrationslager Ravensbrück. Neue Beiträge zur Geschichte und Nachgeschichte, Metropol, Berlin, pp. 219-234.

Landergren Blomqvist, K. (2002). Flyktingar på Malmö Museum 1945. Minnesbilder nedtecknade av Karin Landergren Blomqvist. Malmö Museers skriftserie nr 1, Malmö Museer, Malmö.

Leo, A. (2006). Ravensbrück - Stammlager. In Benz, W., and Distel, B. (eds.), Der Ort des Terrors: Geschichte der nationalsozialistischen Konzentrationslager, Band 4: Flossenbürg, Mauthausen, Ravensbrück, C. H. Beck, München, pp. 473-520.

Levi, P. (1989). The Drowned and the Saved. Rosenthal, R., trans. Vintage Books, New York.

Middleton, D., and Brown, S. D. (2005). The Social Psychology of Experience. Studies in Remembering and Forgetting, Sage, London.

Morrison, J. G. (2000). Ravensbrück. Everyday Life in a Woman's Concentration Camp 1939-45, Markus Weiner, Princeton.

Moshenska, G. (2013). Conflict. In Graves-Brown, P., Harrison, R., and Piccini, A. (eds.), The Oxford Handbook of the Archaeology of the Contemporary World, Oxford University Press, Oxford, pp. 351-363.

Myers, A. T. (2008). Between memory and materiality: an archaeological approach to studying the Nazi concentration camps. Journal of Conflict Archaeology 4(1-2): 231-245.

Myers, A. (2011). The things of Auschwitz. In Myers, A., and Moshenska, G. eds., Archaeologies of Internment, Springer, New York, pp. 75-88. 
Myers, A. (2013). The Archaeology of Reform at a German Prisoner of War Camp in a Canadian National Park during the Second World War (1943-1945). Stanford university Selected Works, Stanford. http://works.bepress.com/adrianmyers/32/.

Myers, A., and Moshenska, G. (2011). An introduction to archaeologies of internment. In Myers, A., and Moshenska, G. eds., Archaeologies of Internment, Springer, New York, pp. 1-19.

Mytum, H. (2013). Materiality matters: The role of things in coping strategies at Cunningham's Camp, Douglas during World War I. In Mytum, H., and Carr, G. eds., Prisoners of War: Archaeology, Memory, and Heritage of 19th- and 20th-Century Mass Internment, Springer, New York, pp. 169-187.

Rudny, P. (n.d.) Polski Instyut Źródłowy w Lund (PIZ), (Polska Källinstitutet i Lund), En presentation av arkivet. http://www3.ub.lu.se/ravensbruck/piz-presentation.pdf, Lund University Library, Lund.

Saidel, R. G. (2006). The Jewish Women of Ravensbrück Concentration Camp, University of Wisconsin Press, Madison.

Saunders, N. (2003). Trench Art: Materialities and Memories of War, Berg, Oxford.

Schofield, J., Gray Johnson, W., and Beck, C. M. (2002). Introduction: Matériel culture in the modern world. In Schofield, J., Gray Johnson, W., and Beck, C. M. eds., Matériel Culture. The Archaeology of Twentieth Century Conflict, Routledge, London, pp. 1-8.

Spitzer, L. (1999). Back through the future: Nostalgic memory and critical memory in a refuge from Nazism. In Bal, M., Crewe, J., and Spitzer, L. (eds.), Acts of Memory: Cultural Recall in the Present, Dartmouth College, Hanover and London, pp. 87-104.

Sturdy Colls, C. (2015). Holocaust Archaeologies. Approaches and Future Directions, Springer, New York.

Theune, C. (2011). Gewalt und Tod in Konzentrations- und Vernichtungslagern. Möglichkeiten und Grenzen der Archäologie. In Morsch, G., and Perz, B. (eds.), Neue Studien zu Nationalsozialistischen Massentötungen durch Giftgas: Historische Bedeutung, technische Entwicklung, revisionistische Leugnung, Metropol Verlag, Berlin, pp. 64-73.

Theune, C. (2015a). Archäologie in ehemaligen Konzentrationslagern. Mitteilungen der Gesellschaft für Landeskunde und Denkmalpflege Oberösterreich 45(2): 7-10.

Theune, C. (2015b). Archäologische Fundmassen und Massenfunde aus enemahligen Konzentrationslagern. In Hofer, N. (ed.), "Massenfunde - Fundmassen. Strategien und Perspektiven im Umgang mit Massenfundkomplexen." Fundberichte aus Österreich. Tagungsband 2, Bundesdenkmalamt, Wien, pp. $37-42$.

Wagenaar, W. A., and Groeneweg, J. (1990). The memory of concentration camp survivors. Applied Cognitive Psychology 4: 77-87.

\section{Databases}

Att överleva. Exhibition at the museum of Kulturen, Lund, Sweden, partly also available on line at http://www. kulturen.com/utstallningar/basutstallningar/att-overleva/

Carlotta artifact database at the museum of Kulturen, Lund, Sweden: http://carl.kulturen.com/web/

Voices from Ravensbrück. Archive at Lund University Library, Sweden: http://www.ub.lu.se/en/voices-fromravensbruck 